\title{
Wat doen S.A. omtrent dwelmmiddels?
}

Die verskynsel van dwelmverslawing is so oud soos die mens self, maar die geweldige omvang en verspreidheid daarvan is 'n hedendaagse verskynsel. Deskundiges is dit daaroor eens dat dit primêr 'n sosiale en persoonlike probleem is. Die wetlike en mediese teenmaatreëls is bloot walgooiery, maar nietemin die onontbeerlike behandeling van simptome.

Dwelmverslawing is die eerste stap op die pad na selfmoord. Dit is selfvernietigend van aard en word algemeen aanvaar as afwykende gedrag (net soos misdaad en prostitusie), en as ' $n$ bedreiging vir die stabiliteit en toekoms van die gemeenskap. Dit word gewoonlik geassosieer met die krisis van adolessensie en word beskou as 'n selfverdedigingsmeganisme teen depressie, wat voortspruit uit 'n gevoel van ontoereikendheid. Volwassenes is beter toegerus om sulke gevoelens te verwerk. Die jeug worstel met die probleem om sy ideale binne realistiese perke te bring. Dikwels is die jongmens nie toegerus om teleurstelling te kan aanvaar nie. Hy sien nie 'n plek vir hom in die samelewing nie - in sommige gevalle ontbreek werksgeleenthede werklik - en 'n duister toekoms staar hom in die gesig. Hierdie frustrasie sowel as die gebrek aan 'n gevoel van eiewaarde laat hom na dwelms gryp om tydelik die drastiese stap van onmiddellike selfvernietiging uit te stel.'

Uit 'n artikel van Sackstein ${ }^{2}$ oor die herintegrasie van gerehabiliteerde jeugdiges in die beroeps- en sosiale lewe, blyk dit dat sowat $15 \%$ van hulle uitgebreide internasionale toetsgroep suksesvol in professionele, tegniese of bestuursposte geplaas is. Hierdie slagoffers het dus gely aan 'n tydelike wanoriëntering, moontlik as gevolg van 'n gebrek aan selfvertroue ten opsigte van hul vermoëns. Geen sektor van die samelewing is dus gevrywaar van die dwelmverslawingsprobleem nie. Die grootste sukses met rehabilitasieprogramme blyk beroepsopleiding volgens individuele behoeftes te wees.

Voorkoming van dwelmverslawing moet dus eerstens op die daarstelling van 'n stabiele samelewing en realistiese waardes en doelstellings gerig wees. Daar moet gewaak word teen die gedagte (dikwels as gevolg van kommersiële advertensieveldtogte) van wondermiddels en kitsoplossings wat geen teenprestasie verg nie. Hierdie benadering verg essensieel 'n opvoedkundige benadering, sedelik, sosiaal en pedagogies, met die gepaardgaande ondersteunende navorsing.

Wetgewing kan die beskikbaarheid van dwelmmiddels beperk, maar verwyder nie die basiese behoefte nie. En daar is altyd plaasvervangers soos alkohol en selfs die inaseming van petroldampe waarmee die behoefte bevredig kan word.

Die medici het die verpligting om die bestaande probleem na die beste van hulle vermoë te hanteer. Maar dit is weer eens nie 'n geïsoleerde poging nie, aangesien mediese behandeling alleen nie volledige rehabilitasie kan bewerkstellig nie.

Voorkomende maatreëls vereis 'n breë spektrum van aksie wat inligting, onderwys, opvoeding, aktiwiteite van die polisie en doeane, en die dienste van mediese en sosiale instansies insluit.

Die W.G.O. het verskeie programme ingestel wat ' $n$ wye verskeidenheid van optrede dek en baie lande doen op eie houtjie hul deel om die vraagstuk te bekamp. Hele bevolkings is byvoorbeeld suksesvol gemotiveer om ander gewasse as die opiumdraende papawer te plant, soos in Birma.

Die vraag ontstaan dus wat Suid-Afrika op die gebied doen. Doen ons op die sedelike en opvoedkundige voorkomingsfront iets om ons jeug te ontmoedig teen dwelmmiddels deur positiewe en realistiese waardes voor te hou, eerder as om te konsentreer op die negatiewe aspekte van die gevaar wat dit inhou. Daar is bewys dat laasgenoemde benadering nie ' $n$ afskrikmiddel is as depressie eers posgevat het nie, maar juis positief werk omdat selfvernietiging die uiteindelike doel is.

Ons weet dat wetgewing bestaan omtrent die aanplant, verkoop en gebruik van dwelmmiddels en verneem van tyd tot tyd deur die media van daadwerklike optrede. Ons weet ook dat daar mediese behandeling vir verslaafdes is, sowel as rehabilitasiesentrums. Maar is dit voldoende? Doen ons self enigsins navorsing oor die chemiese en farmakologiese werking en die teenwerking van dwelmmiddels, of maak ons bloot staat op die bevindings van ons oorsese kollegas? Wat is die omvang van die probleem in SuidAfrika? Hoe vergelyk dit met ander lande, veral waar daar 'n homogene gemeenskap (een taal, een kultuur, een godsdiens) met 'n eeue-oue tradisionele lewenswyse is?

\section{VERWYSINGS}

1. Bergeret, J. (1981). Young people, drugs . . . and others, Bulletin on Narcotics, 33 (4), 4.

2. Sackstein, E. (1981). Drugs and Youth: an international perspective on vocational and social reintegration, Bulletin on Narcotics, 33 (4), 37. 